(2) Open Access Full Text Article

\title{
A real-life experience of sorafenib treatment for patients with advanced hepatocellular carcinoma: a retrospective analysis at Cathay General Hospital, 2007-20I5
}

This article was published in the following Dove Medical Press journal: Drug Design, Development and Therapy

\author{
Chi-Chun Huang' \\ Hsin-Yi Chen' \\ Ruei-Hsin Chang' \\ Pen-An Liao ${ }^{2}$ \\ Heng-Hui Lien ${ }^{3,4}$ \\ Chih-Sheng Hung 5 \\ Sien-Sing Yang ${ }^{1,3}$ \\ Jui-Ting $\mathrm{Hu}^{1,3}$ \\ 'Liver Center, Cathay General \\ Hospital Medical Center, Taipei, \\ Taiwan; ${ }^{2}$ Department of Radiology, \\ Cathay General Hospital Medical \\ Center, Taipei, Taiwan; ${ }^{3}$ School of \\ Medicine, Fu-Jen Catholic University \\ College of Medicine, Taipei, Taiwan; \\ ${ }^{4}$ Department of Surgery, Cathay \\ General Hospital Medical Center, \\ Taipei, Taiwan; ${ }^{5}$ Department of \\ Gastroenterology, Cathay General \\ Hospital Medical Center, Taipei, Taiwan
}

Correspondence: Jui-Ting Hu Liver Center, Cathay General Hospital Medical Center, No 280, Sec 4, Ren Ai Road, Taipei 10630, Taiwan, Republic of China

Tel +886227082121 ext 3123

Fax +886266367420

Email huyeh0203@gmail.com
Background: Sorafenib is an oral tyrosine kinase inhibitor that is indicated for advanced hepatocellular carcinoma (HCC). The aim of the present study was to determine the clinical outcomes of HCC patients receiving sorafenib in real-life clinical setting in comparison with formal clinical trials.

Methods: Patients diagnosed with advanced HCC between 2007 and 2015 at single institute were retrospectively enrolled and evaluated for survival and tolerability following sorafenib treatment. Overall survival (OS) and duration of treatment (TTP) were examined by different stratifications including age, gender, etiology, liver functions, and severities.

Results: A total of 67 advanced HCC patients were enrolled for analysis. Of the 67 eligible patients, 66 patients $(99 \%)$ were diagnosed as Barcelona Clinic Liver Cancer stage C and 45 (67\%) were Child-Pugh A. Chronic hepatitis B virus infection was the main etiology (67\%), followed by hepatitis $\mathrm{C}$ virus infection (12\%) and alcohol liver disease (8\%). The median duration of treatment was 3.0 months (95\% CI 2.6-3.4 months) and median OS was 8.0 months (95\% CI 5.0-11.0 months). By multivariate analysis, female gender ( $\mathrm{HR}=2.462$, 95\% CI 1.126-5.387, $P=0.024)$, Child-Pugh C (HR =3.913, 95\% CI 1.063-14.410, $P=0.04)$, extrahepatic spread (HR $=2.123,95 \%$ CI $1.122-4.015, P=0.021)$, and combined other therapies (HR $=0.410,95 \%$ CI $0.117-0.949, P=0.037)$ were the independent predictors of OS.

Conclusion: OS of advanced HCC patients treated with sorafenib was longer than that reported in the Asia-Pacific trial study. Impaired hepatic functions are associated with the shorter survival in real-life setting.

Keywords: advanced hepatocellular carcinoma, sorafenib, liver function, tumor burden

\section{Introduction}

Hepatocellular carcinoma (HCC) is one of the most prevalent liver malignancies. It is prevalent in Asian countries in association with chronic hepatitis B and chronic hepatitis C. ${ }^{1,2}$ Although $20 \%$ of HCC patients are diagnosed at an early stage, patients with intermediate stage suffer from poor prognosis due to unfavorable response to standard-of-care locoablative treatments like transarterial chemoembolization (TACE) or radiofrequency ablation (RFA). ${ }^{3}$ Moreover, most HCC patients are diagnosed at an advanced stage when curative therapies such as surgical resection or liver transplantation are not possible. ${ }^{4}$

Sorafenib is an oral tyrosine kinase inhibitor that targets Raf serine/threonine kinase isoforms in Raf/MEK/ERK pathway as well as upstream receptor tyrosine kinases 
involved in angiogenesis including vascular endothelial growth factor receptor (VEGFR)-2, VEGFR-3, plateletderived growth factor receptor (PDGFR)-b, c-KIT, FLT-3, and RET. ${ }^{5,6}$ Sorafenib has been shown to block cell proliferation and angiogenesis resulting in improved survival of patients with advanced HCC. ${ }^{7}$ The Sorafenib HCC Assessment Randomized Protocol (SHARP) and the Asia-Pacific (AP) trials have shown a significantly prolonged overall survival (OS). ${ }^{89}$ Despite the clinical benefits of sorafenib, adverse effects have been reported to be variable from patient to patient, including diarrhea, fatigue, and hand-foot syndrome. The large variability in activity and tolerability of sorafenib has been attributed to interindividual variability in drug kinetics such as bioavailability. Moreover, several studies under real-life conditions have proposed different results concerning the effectiveness and safety profile of sorafenib in HCC patients. ${ }^{10-12}$ However, additional data on benefits and risks of sorafenib in real-life clinical setting are required.

Despite the existence of numerous studies on the efficacy of sorafenib, there is a lack of information on therapeutic role of sorafenib as concurrent treatment in real-life HCC patients who undergo combination treatments. The present study was designed to evaluate the effectiveness of sorafenib in HCC patients with advanced Barcelona Clinic Liver Cancer (BCLC) stage, or intermediate stage treated with sorafenib in real-life practice conditions. Prognostic factors of survival in HCC patients treated with sorafenib were determined.

\section{Materials and methods Patients}

We retrospectively reviewed medical records of patients with advanced HCC at Cathay General Hospital between January 2007 and March 2017 (Figure 1). The study population included patients with advanced-stage HCC confirmed by histological or cytological analysis or diagnosed by noninvasive assessment per American Association for the Study of Liver Disease criteria.

Patients previously receiving local therapy (eg, surgery, radiation, hepatic artery embolization, TACE, RFA, percutaneous ethanol injection, or cryoablation) were eligible under following conditions: local therapy is completed at least 4 weeks before study entry and all toxic effects associated with prior treatments are resolved. Other inclusion criteria included Child-Pugh Class A, Eastern Cooperative Oncology Group (ECGO) performance status of $0-1$, aspartate transminase and alanine transminase $\leq 5$ times upper limit of normal, bilirubin $\leq 3 \mathrm{mg} / \mathrm{dL}$, adequate renal function (serum creatinine $\leq 1.5$ times the upper limit of the normal range), advanced

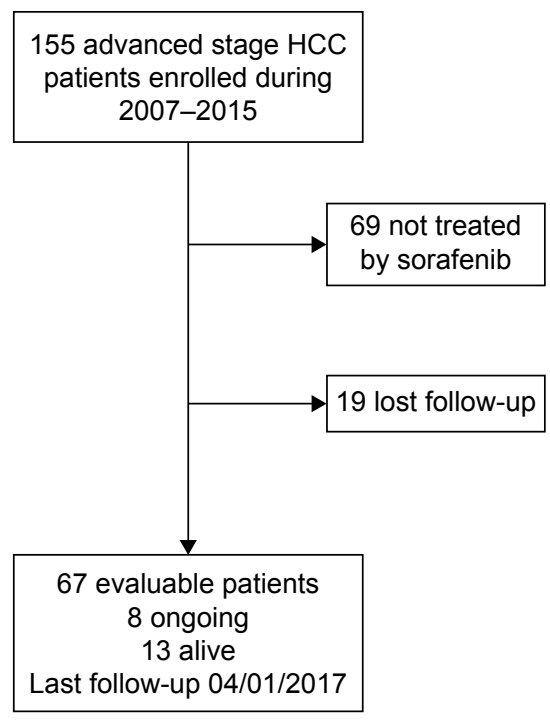

Figure I Consort diagram.

Abbreviations: HCC, hepatocellular carcinoma.

HCC not amenable to curative resection, distal metastasis (bone or lung) or portal vein thrombosis (VP3 or VP4), and life expectancy of 12 weeks or more. Patients were excluded under following criteria including any history of hepatic encephalopathy and prior or current clinically significant ascites and active hepatitis $\mathrm{B}$ virus (HBV) and hepatitis $\mathrm{C}$ virus $(\mathrm{HCV})$ co-infection. The study protocol was reviewed and approved by institutional review board of Cathay General Hospital (Cathay Hospital IRB: P106038). This study was conducted in compliance with the guidelines of good clinical practice and the principles of the Declaration of Helsinki. Since this study did not investigate privacy issues involving patient names, ID numbers, home addresses, phone numbers, etc. Therefore, patient consent to review their medical records was not required by the Cathay General Hospital IRB.

\section{Treatment}

Patients were prescribed with sorafenib $400 \mathrm{mg}$ twice daily. Sorafenib treatment was continued until the occurrence of both radiologic progression, as defined by Response Evaluation Criteria In Solid Tumors, and symptomatic progression, as defined by the Functional Assessment of Cancer Therapy-Hepatobiliary Symptom Index 8 questionnaire, or the occurrence of either unacceptable adverse events or death.

\section{Statistical analyses}

All data were collected by experienced medical personnel involved in the study. OS and duration of treatment were analyzed by Kaplan-Meier analysis. Categorical variables were analyzed and presented in frequency and percentages. 
The following variables were used for univariate analysis: age, gender, Child-Pugh score, HBV infection, alphafetoprotein (AFP) level, portal vein invasion, extrahepatic spread, combined with other therapy(s), and initial dose. Results were presented in HR and 95\% CI, calculated from a Cox regression analysis.

\section{Results}

\section{Baseline characteristics}

A total of 67 consecutive patients with advanced HCC were included during the study period. The data of baseline demographic patients are presented in Table 1. About 79\% (53/67) of enrolled patients were male and the median age was 65 (38-83) years. Of them, 66 patients (99\%) were diagnosed as BCLC stage C. Chronic HBV infection was the main etiology $(67 \%)$, followed by $\mathrm{HCV}$ infection $(12 \%)$ and alcohol

Table I Baseline characteristics of the HCC patients receiving sorafenib treatment

\begin{tabular}{|c|c|}
\hline Advanced HCC, $n=67$ & \\
\hline Median age, years (range) & $65(38-83)$ \\
\hline Male, n (\%) & $53(79)$ \\
\hline $\begin{array}{l}\text { Portal vein invasion, } n(\%) \\
\text { Yes } \\
\text { No }\end{array}$ & $\begin{array}{l}52(78) \\
15(22)\end{array}$ \\
\hline $\begin{array}{l}\text { Extrahepatic spread, n (\%) } \\
\text { Lung } \\
\text { Bone } \\
\text { Lymph node }\end{array}$ & $\begin{array}{l}14(2 I) \\
8(12) \\
7(10)\end{array}$ \\
\hline BCLC stage C, n (\%) & $66(99)$ \\
\hline $\begin{array}{l}\text { Etiology, n (\%) } \\
\text { HBV } \\
\text { HCV } \\
\text { Alcohol } \\
\text { Others }\end{array}$ & $\begin{array}{l}45(67) \\
12(22) \\
8(12) \\
4(6)\end{array}$ \\
\hline \multicolumn{2}{|l|}{ Child-Pugh class, n (\%) } \\
\hline $\begin{array}{l}\text { Class A } \\
\text { Class B } \\
\text { Class C }\end{array}$ & $\begin{array}{l}45(67) \\
19(28) \\
3(4)\end{array}$ \\
\hline \multicolumn{2}{|l|}{ AFP $\geqq 20$ ng/mL, n (\%) } \\
\hline $\begin{array}{l}\text { No } \\
\text { Yes }\end{array}$ & $\begin{array}{l}20(30) \\
46(69)\end{array}$ \\
\hline \multicolumn{2}{|c|}{ Combine with other therapy, $\mathrm{n}(\%)$} \\
\hline $\begin{array}{l}\text { TAE or TACE } \\
\text { RT } \\
\text { HAIC } \\
\text { OP } \\
\text { Systemic chemotherapy } \\
\text { None }\end{array}$ & $\begin{array}{l}35(52) \\
34(51) \\
9(13) \\
9(13) \\
2(3) \\
9(13)\end{array}$ \\
\hline
\end{tabular}

Abbreviations: AFP, alpha-fetoprotein; BCLC, Barcelona Clinic Liver Cancer; HAIC, hepatic arterial infusion chemotherapy; HBV, hepatitis B virus; HCC, hepatocellular carcinoma; HCV, hepatitis $C$ virus; OP, operation; RT, radiotherapy; TACE, transarterial chemoembolization; TAE, transarterial embolization. liver disease (8\%). According to Child-Pugh score, 45 (67\%) patients were classified as class A, followed by class B (28\%). About $64 \%$ of patients underwent radiotherapy in combination with sorafenib, while $52 \%$ were given transarterial embolization or TACE. Nine patients underwent surgery and nine patients had hepatic arterial infusion chemotherapy.

\section{Survivals}

The median duration of treatment was 3.0 months $(95 \%$ CI 2.6-3.4 months) and the median OS was 8.0 months (95\% CI 5.0-11.0 months) (Figure 2A and B). The median duration of treatment in Child-Pugh A patients was longer than that of Child-Pugh $\mathrm{C}(P=0.02)$, whereas there was no significant difference in median OS among all groups (Figure 3A and B). Patients with an AFP level $<400 \mathrm{ng} / \mathrm{mL}$ exhibited significantly longer duration of treatment survival (4.2 months; 95\% CI 0-9.9 months) compared with that of the patients with an AFP $>400 \mathrm{ng} / \mathrm{mL}(P=0.045)$ (Figure 4). There was no statistically significant difference in OS based on portal vein invasion, extrahepatic spread, HBV, gender, and age.

We next performed a univariate analysis to exam the association of variables with duration of treatment in the advanced $\mathrm{HCC}$ patients receiving sorafenib. Clinical variables associated with increased duration of treatment included severely impaired liver function (Child-Pugh C). Multivariate analysis confirmed Child-Pugh $\mathrm{C}$ as an independent predictor of duration of treatment (Table 2). By multivariate analysis, female gender ( $\mathrm{HR}=2.462,95 \%$ CI $1.126-5.387$, $P=0.024)$, Child-Pugh C $(\mathrm{HR}=3.913,95 \%$ CI 1.063 14.410, $P=0.04)$, extrahepatic spread $(\mathrm{HR}=2.123,95 \%$ CI 1.122-4.015, $P=0.021)$, and combined other therapies (HR $=0.410,95 \%$ CI $0.117-0.949, P=0.037)$ were the independent predictors of OS (Table 3 ).

\section{Discussion}

In this retrospective study, we collected and analyzed the clinical outcomes of advanced HCC patients who underwent treatment with sorafenib in real-life clinical setting. We found that HCC patients with Child-Pugh A exhibited a significantly higher median survival. We showed significant differences in duration of treatment for patients with AFP levels $<400 \mathrm{ng} / \mathrm{mL}$. In the present study, factors that are predictive of OS in HCC patient treated with sorafenib include gender, extrahepatic spread, and combined other therapies.

Sorafenib has been prescribed as first-line treatment for patients with advanced-stage HCC based on improved OS reported by two large Phase III trials. ${ }^{9,13}$ These trials mainly included $\mathrm{HCC}$ patients of Child-Pugh class A, BCLC stage C, 
A

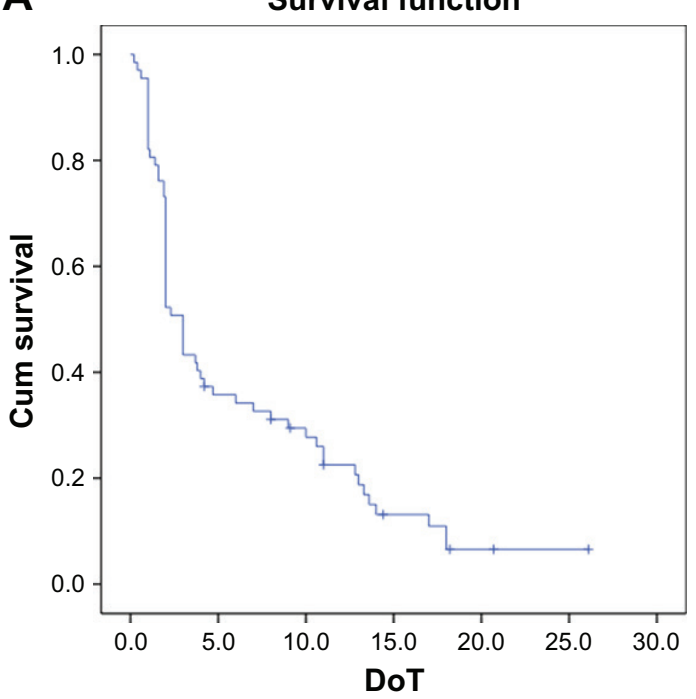

B

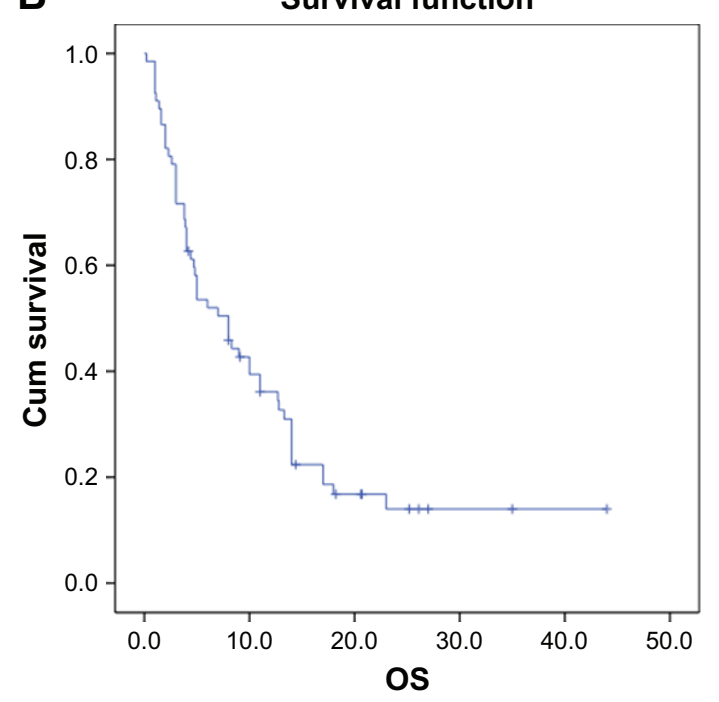

$\neg$ Survival function + Censored

Figure 2 Kaplan-Meier analysis of (A) duration of treatment and (B) overall survival of all eligible HCC patients. Abbreviations: HCC, hepatocellular carcinoma; DoT, duration of treatment; OS, overall survival.

and an Eastern Cooperative Oncology Group status of 0-2. Owing to the selective nature of the trial enrollment, a broad spectrum of HCC patients were not included in these studies. In addition to advanced $\mathrm{HCC}$, sorafenib therapy has been recommended for intermediate-stage $\mathrm{HCC}$ by several guidelines. In our study, HCC patients treated with sorafenib had median
OS of 8.0 months, which is shorter than that reported in SHARP (10.5 months) and GIDEON (Global Investigation of therapeutic DEcisions in HCC and Of its treatment with sorafeNib) (10.8 months). Interestingly, median OS reported herein is higher than that reported in the AP Phase III study (6.5 months) conducted in Asia-Pacific region. A recent study
A

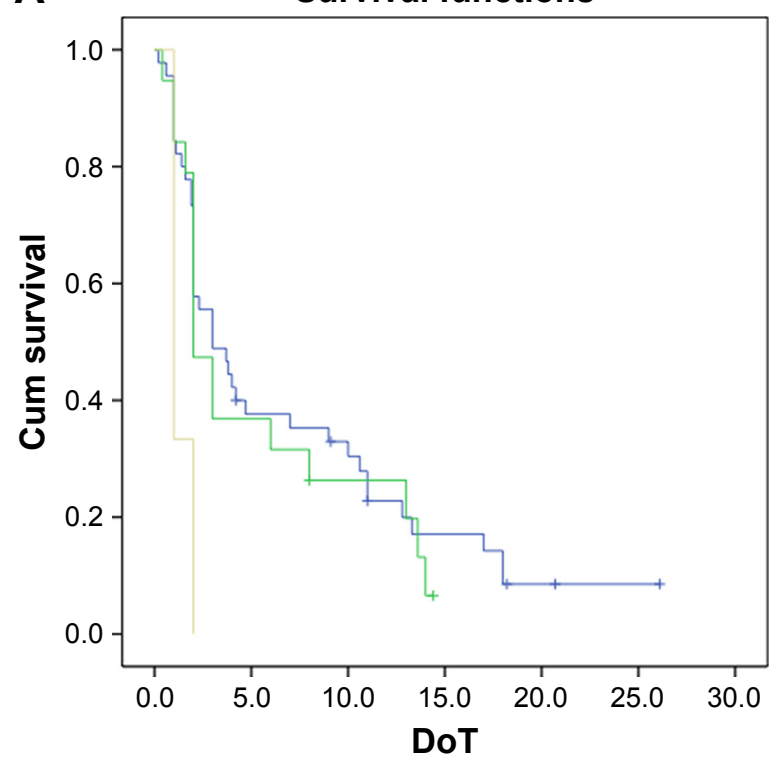

B

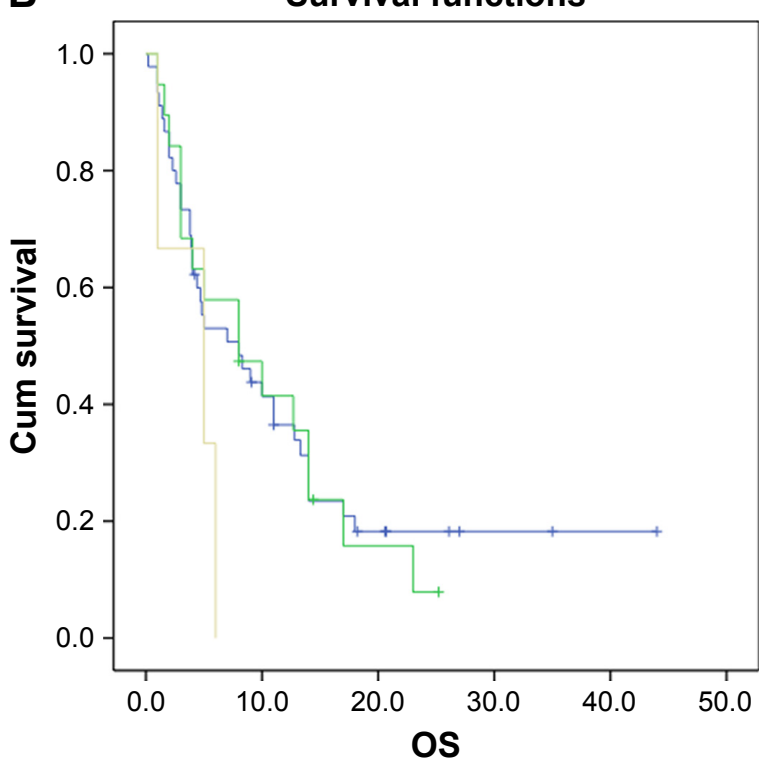

Figure 3 Kaplan-Meier analysis of (A) duration of treatment and (B) overall survival of HCC patients with different Child-Pugh scores. Abbreviations: HCC, hepatocellular carcinoma; DoT, duration of treatment; OS, overall survival; CP, Child-Pugh. 
A

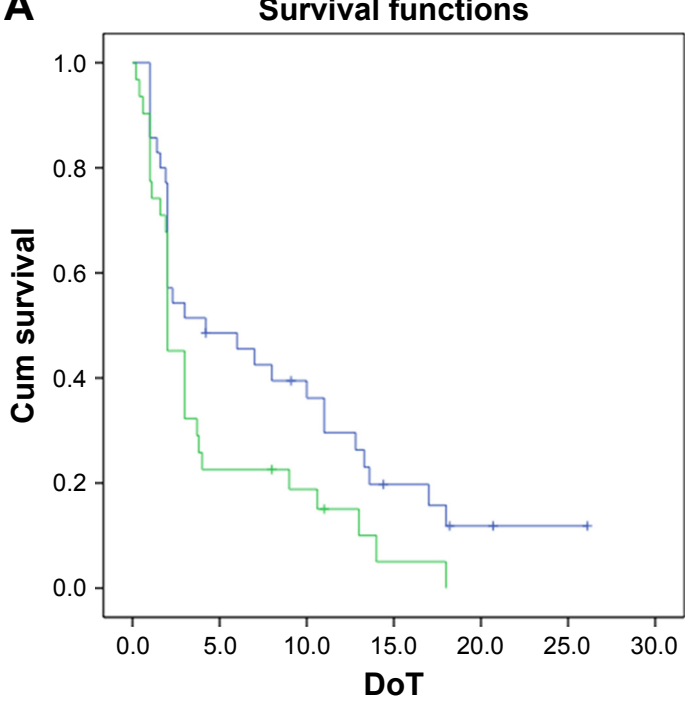

B Survival functions

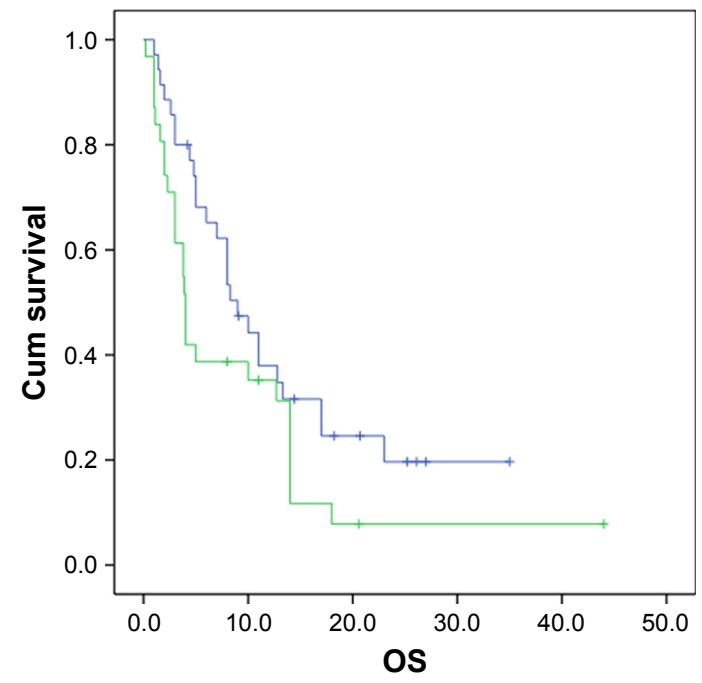

\begin{tabular}{|l} 
AFP \\
$\neg<400 \mathrm{ng} / \mathrm{mL} \quad-\geq 400 \mathrm{ng} / \mathrm{mL} \quad+<400 \mathrm{ng} / \mathrm{mL}$-censored $\quad+\geq 400 \mathrm{ng} / \mathrm{mL}$-censored
\end{tabular}

Figure 4 Kaplan-Meier analysis of (A) duration of treatment and (B) overall survival of HCC patients with AFP level $>400 \mathrm{ng} / \mathrm{mL}$.

Abbreviations: HCC, hepatocellular carcinoma; DoT, duration of treatment; OS, overall survival; AFP, alpha-fetoprotein.

Table 2 Univariate and multivariate analyses of factors associated with duration of treatment in HCC patients treated with sorafenib

\begin{tabular}{|c|c|c|c|c|c|c|c|}
\hline \multirow[t]{2}{*}{ Variables } & \multirow[t]{2}{*}{$n$} & \multicolumn{3}{|c|}{ Univariate analysis } & \multicolumn{3}{|c|}{ Multivariate analysis } \\
\hline & & HR & $95 \% \mathrm{Cl}$ & $P$-value & HR & $95 \% \mathrm{Cl}$ & $P$-value \\
\hline $\begin{array}{l}\text { Age (years) } \\
\quad<65 \\
\geqq 65\end{array}$ & $\begin{array}{l}33 \\
34\end{array}$ & $\begin{array}{l}\text { I } \\
0.948\end{array}$ & $(0.566-1.585)$ & 0.838 & $\begin{array}{l}1 \\
1.044\end{array}$ & $(0.595-1.831)$ & 0.880 \\
\hline $\begin{array}{l}\text { Gender } \\
\text { Male } \\
\text { Female }\end{array}$ & $\begin{array}{l}53 \\
14\end{array}$ & $\begin{array}{l}1 \\
0.963\end{array}$ & $(0.50 \mathrm{I}-\mathrm{I} .820)$ & 0.908 & $\begin{array}{l}1 \\
1.118\end{array}$ & $(0.533-2.348)$ & 0.768 \\
\hline $\begin{array}{l}\text { Child-Pugh status } \\
\text { A } \\
\text { B } \\
\text { C }\end{array}$ & $\begin{array}{l}45 \\
19 \\
3\end{array}$ & $\begin{array}{l}1 \\
1.154 \\
3.554\end{array}$ & $\begin{array}{l}(0.648-2.057) \\
(1.056-11.967)\end{array}$ & $\begin{array}{l}0.626 \\
0.04 I^{*}\end{array}$ & $\begin{array}{l}1 \\
1.062 \\
4.467\end{array}$ & $\begin{array}{l}(0.535-2.106) \\
(1.190-16.768)\end{array}$ & $\begin{array}{l}0.864 \\
0.027^{*}\end{array}$ \\
\hline $\begin{array}{l}\text { HBV } \\
\text { No } \\
\text { Yes }\end{array}$ & $\begin{array}{l}22 \\
45\end{array}$ & $\begin{array}{l}1 \\
1.070\end{array}$ & $(0.614-1.865)$ & $0.8 \mathrm{II}$ & $\begin{array}{l}1 \\
0.926\end{array}$ & $(0.502-1.709)$ & 0.807 \\
\hline $\begin{array}{l}\operatorname{AFP}(\mathrm{ng} / \mathrm{mL}) \\
\quad<20 \\
\quad \geq 20\end{array}$ & $\begin{array}{l}20 \\
46\end{array}$ & $\begin{array}{l}1 \\
1.662\end{array}$ & $(0.920-3.003)$ & 0.092 & & & \\
\hline $\begin{array}{l}\text { Portal vein invasion } \\
\text { No } \\
\text { Yes }\end{array}$ & $\begin{array}{l}15 \\
52\end{array}$ & $\begin{array}{l}1 \\
0.929\end{array}$ & $(0.499-1.73 I)$ & 0.817 & $\begin{array}{l}1 \\
1.240\end{array}$ & $(0.574-2.68 I)$ & 0.584 \\
\hline $\begin{array}{l}\text { Extrahepatic spread } \\
\text { No } \\
\text { Yes }\end{array}$ & $\begin{array}{l}38 \\
29\end{array}$ & $\begin{array}{l}1 \\
1.282\end{array}$ & $(0.767-2.142)$ & 0.343 & $\begin{array}{l}1 \\
1.603\end{array}$ & $(0839-3.061)$ & 0.153 \\
\hline $\begin{array}{l}\text { Combined with other therapy(s) } \\
\text { No } \\
\text { Yes }\end{array}$ & $\begin{array}{l}9 \\
58\end{array}$ & $\begin{array}{l}1 \\
0.629\end{array}$ & $(0.307-1.286)$ & 0.204 & $\begin{array}{l}\text { I } \\
0.528\end{array}$ & $(0.24|-| .158)$ & 0.111 \\
\hline $\begin{array}{l}\text { Initial dose }(\mathrm{ng} / \mathrm{mL}) \\
\quad 800 \\
\leq 400\end{array}$ & $\begin{array}{l}48 \\
19\end{array}$ & $\begin{array}{l}1 \\
1.266\end{array}$ & $(0.726-2.209)$ & 0.406 & $\begin{array}{l}1 \\
1.207\end{array}$ & $(0.67 I-2.173)$ & 0.530 \\
\hline
\end{tabular}

Note: $* P$-value $<0.05$.

Abbreviations: HCC, hepatocellular carcinoma; HBV, hepatitis B virus; AFP, alpha-fetoprotein. 
Table 3 Univariate and multivariate analyses of factors associated with overall survival in HCC patients treated with sorafenib

\begin{tabular}{|c|c|c|c|c|c|c|c|}
\hline \multirow[t]{2}{*}{ Variables } & \multirow[t]{2}{*}{$\mathbf{n}$} & \multicolumn{3}{|c|}{ Univariate analysis } & \multicolumn{3}{|c|}{ Multivariate analysis } \\
\hline & & HR & $95 \% \mathrm{Cl}$ & $P$-value & HR & $95 \% \mathrm{Cl}$ & $P$-value \\
\hline $\begin{array}{l}\text { Age (years) } \\
\quad<65 \\
\quad \geqq 65\end{array}$ & $\begin{array}{l}33 \\
34\end{array}$ & $\begin{array}{l}1 \\
0.88 I\end{array}$ & $(0.5 \mid 5-1.508)$ & 0.645 & $\begin{array}{l}1 \\
0.915\end{array}$ & $(0.504-1.662)$ & 0.770 \\
\hline $\begin{array}{l}\text { Gender } \\
\text { Male } \\
\text { Female }\end{array}$ & $\begin{array}{l}53 \\
14\end{array}$ & $\begin{array}{l}1 \\
1.606\end{array}$ & $(0.836-3.084)$ & 0.155 & $\begin{array}{l}1 \\
2.462\end{array}$ & $(1.126-5.387)$ & $0.024 *$ \\
\hline $\begin{array}{l}\text { Child-Pugh status } \\
\text { A } \\
\text { B } \\
\text { C }\end{array}$ & $\begin{array}{l}45 \\
19 \\
3\end{array}$ & $\begin{array}{l}1 \\
1.031 \\
2.430\end{array}$ & $\begin{array}{l}(0.570-1.865) \\
(0.729-8.106)\end{array}$ & $\begin{array}{l}0.919 \\
0.149\end{array}$ & $\begin{array}{l}1 \\
1.232 \\
3.913\end{array}$ & $\begin{array}{l}(0.609-2.49 I) \\
(1.063-14.410)\end{array}$ & $\begin{array}{l}0.562 \\
0.040^{*}\end{array}$ \\
\hline $\begin{array}{l}\text { HBV } \\
\text { No } \\
\text { Yes }\end{array}$ & $\begin{array}{l}22 \\
45\end{array}$ & $\begin{array}{l}1 \\
1.110\end{array}$ & $(0.624-1.976)$ & 0.722 & $\begin{array}{l}1 \\
1.158\end{array}$ & $(0.611-2.195)$ & 0.652 \\
\hline $\begin{array}{l}\text { AFP }(\mathrm{ng} / \mathrm{mL}) \\
\quad<20 \\
\quad \geq 20\end{array}$ & $\begin{array}{l}20 \\
46\end{array}$ & $\begin{array}{l}1 \\
1.460\end{array}$ & $(0.792-2.692)$ & 0.226 & & & \\
\hline $\begin{array}{l}\text { Portal vein invasion } \\
\text { No } \\
\text { Yes }\end{array}$ & $\begin{array}{l}15 \\
52\end{array}$ & $\begin{array}{l}1 \\
1.086\end{array}$ & $(0.506-2.108)$ & 0.807 & $\begin{array}{l}1 \\
2.049\end{array}$ & $(0.939-4.470)$ & 0.072 \\
\hline $\begin{array}{l}\text { Extrahepatic spread } \\
\text { No } \\
\text { Yes }\end{array}$ & $\begin{array}{l}38 \\
29\end{array}$ & $\begin{array}{l}1 \\
1.424\end{array}$ & $(0.832-2.439)$ & 0.198 & $\begin{array}{l}1 \\
2.123\end{array}$ & $(1.122-4.015)$ & $0.021 *$ \\
\hline $\begin{array}{l}\text { Combined with other therapy(s) } \\
\text { No } \\
\text { Yes }\end{array}$ & $\begin{array}{l}9 \\
58\end{array}$ & $\begin{array}{l}1 \\
0.623\end{array}$ & $(0.293-1.324)$ & 0.219 & $\begin{array}{l}1 \\
0.410\end{array}$ & $(0.117-0.949)$ & $0.037^{*}$ \\
\hline $\begin{array}{l}\text { Initial dose }(\mathrm{ng} / \mathrm{mL}) \\
\quad 800 \\
\leq 400\end{array}$ & $\begin{array}{l}48 \\
19\end{array}$ & $\begin{array}{l}1 \\
1.255\end{array}$ & $(0.705-2.23 I)$ & 0.440 & 1.310 & $(0.7 \mid 4-2.405)$ & 0.383 \\
\hline
\end{tabular}

Note: *P-value $<0.05$.

Abbreviations: HCC, hepatocellular carcinoma; HBV, hepatitis B virus; AFP, alpha-fetoprotein.

reported that there was no significant difference in OS between Asian and Caucasian HCC patients treated with sorafenib, ${ }^{14}$ suggesting that ethnicity is not associated with OS in advanced HCC patients treated with sorafenib. The differences among these clinical trials and field-practice studies are explained by varying composition of the study populations such as the type of viral hepatitis, liver functions, and severities in each study. Of the HCC patients enrolled in this study, $67 \%$ and $22 \%$ had chronic HBV and HCV infections, respectively, compared to $20 \%$ and $51 \%$ in the SOFIA (Sorafenib Italian Assessment) study. ${ }^{11}$ Chronic HCV infection has been associated with better OS in $\mathrm{HCC}$ patients treated with sorafenib, ${ }^{12,14}$ whereas HBV is not. In addition to etiology, impaired liver function has been correlated to shorter OS. ${ }^{15}$ Our cohorts had higher proportion of Child-Pugh B (28\%) compared to that of SHARP study (5\%), explaining the discrepancy in OS between present study and prior trials. This suggests that effectiveness of sorafenib was negatively correlated with liver function in routine clinical practice. In contrast to the AP study, the longer OS reported in current study is postulated to be attributed to the better understanding of the use of sorafenib and more experience in adverse event management. Further studies are necessary to elucidate the influence of geographical factor on responses to sorafenib treatment.

Sorafenib is generally considered to be tolerable in advanced HCC patients. Poor tolerability to sorafenib results in dose reduction and discontinuation, leading to poor outcomes..$^{11}$ Our data showed that the patients enrolled in this study exhibited a median duration of treatment of 3 months, which is comparable to that reported in GIDEON study (11.7 weeks). When stratified by Child-Pugh score, Child-Pugh A patients had longer treatment duration (3.0 months) with relatively favorable OS (8 months). This finding is similar to the results of SOFIA study showing a median treatment duration of 4.2 months (95\% CI 3.4-5.0) in Child-Pugh A patients. ${ }^{11}$ In SOFIA study, the short treatment 
duration was attributed to adverse events and liver function deterioration. Ganten et al reported a median treatment duration of 26.1 weeks for Child-Pugh A patients vs 14.5 weeks for Child-Pugh B patients. ${ }^{10}$ In contrast, in Lee et al study which had similar proportion of Child-Pugh A (66\%) patients, the median duration of sorafenib treatment was 67 days (range 14-452 days), which is inferior to previous trials. It is suggested that baseline Child-Pugh score is correlated with duration of treatment as well as effectiveness. In addition to liver function, a recent study reports racial differences in the efficacy of sorafenib in terms of treatment duration. ${ }^{16}$

High tumor burden is associated with poor prognosis of patients with HCC due to limited treatment options and the influence on therapy efficacy. Portal vein invasion and extrahepatic spread are suggested to be independent factors for mortality in HCC patients. ${ }^{17,18}$ In the present study, multivariate analysis identified extrahepatic spread as an independent predictor of OS in advanced HCC patients treated with sorafenib. This finding is in line with the results of Sinn et al's study reporting that extrahepatic spread and portal vein invasion are associated with poor survival in Korean HCC patients with BCLC stage C. ${ }^{19}$ In contrast, our study showed portal vein invasion was associated with neither poor prognosis nor short treatment duration. The discrepancy may be due to the difference in inclusion criteria, as in Sinn et al's study, the patients included were all BCLC stage C. Although sorafenib is the only systemic therapy for advanced HCC, a variety of modalities have been practiced in real world. Combinations of sorafenib with other locoregional therapy have been shown to prolong the survival of patients with advanced HCC. Use of sorafenib plus radiotherapy has resulted in prolonged survival of advanced HCC patients in comparison of treatment with sorafenib alone. ${ }^{20}$ Sorafenib plus TACE has been shown to be more effective than TACE monotherapy for treating patients with advanced HCC. ${ }^{21,22} \mathrm{We}$ found that sorafenib combined with other therapy resulted in relatively prolonged survival of HCC patients. Our data suggest that combination with other therapies is an independent predictor of OS in advanced HCC patients.

There are several limitations in this study, mainly derived from the nature of retrospective design. Being a retrospective study, it is difficult to ascertain the actual cause of death in our cohort. The population size examined in our study is relatively small, which may limit the statistical power. Small population size may have influences on subgroup analysis. Other limitations include the reduced initial dose of sorafenib based on clinical decision made by individual physicians and adjustment of dosages during treatment due to intolerance.

\section{Conclusion}

Clinical outcomes of advanced HCC patients treated with sorafenib in real-life practice are better compared to the other studies conducted in the Asia-Pacific region in terms of survival and tolerability. Extrahepatic spread and combination with other therapies are of predictive value for OS of advanced HCC. Further studies are required to maximize the effect of sorafenib in combination with other modalities.

\section{Disclosure}

The authors report no conflicts of interest in this work.

\section{References}

1. Goh GB, Chang PE, Tan CK. Changing epidemiology of hepatocellular carcinoma in Asia. Best Pract Res Clin Gastroenterol. 2015;29(6): 919-928.

2. Barazani Y, Hiatt JR, Tong MJ, Busuttil RW. Chronic viral hepatitis and hepatocellular carcinoma. World J Surg. 2007;31(6):1243-1248.

3. Sacco R, Tapete G, Simonetti N, et al. Transarterial chemoembolization for the treatment of hepatocellular carcinoma: a review. J Hepatocell Carcinoma. 2017;4:105-110.

4. Forner A, Llovet JM, Bruix J. Hepatocellular carcinoma. Lancet. 2012; 379(9822):1245-1255.

5. Huynh H, Ong RW, Li PY, et al. Targeting receptor tyrosine kinase pathways in hepatocellular carcinoma. Anticancer Agents Med Chem. 2011;11(6):560-575.

6. Cervello M, Bachvarov D, Lampiasi N, et al. Molecular mechanisms of sorafenib action in liver cancer cells. Cell Cycle. 2012;11(15): 2843-2855.

7. Wörns MA, Galle PR. Sorafenib for the treatment of hepatocellular carcinoma. Hepat Oncol. 2014;1(2):189-204.

8. Rimassa L, Santoro A. Sorafenib therapy in advanced hepatocellular carcinoma: the SHARP trial. Expert Rev Anticancer Ther. 2009;9(6): 739-745.

9. Cheng AL, Kang YK, Chen Z, et al. Efficacy and safety of Sorafenib in patients in the Asia-Pacific region with advanced hepatocellular carcinoma: a phase III randomised, double-blind, placebo-controlled trial. Lancet Oncol. 2009;10(1):25-34.

10. Ganten TM, Stauber RE, Schott E, et al. Sorafenib in Patients with Hepatocellular Carcinoma-Results of the Observational INSIGHT Study. Clin Cancer Res. 2017;23(19):5720-5728.

11. Iavarone M, Cabibbo G, Piscaglia F, et al; SOFIA (SOraFenib Italian Assessment) study group. Field-practice study of Sorafenib therapy for hepatocellular carcinoma: a prospective multicenter study in Italy. Hepatology. 2011;54(6):2055-2063.

12. Lencioni R, Kudo M, Ye SL, et al. First interim analysis of the GIDEON (Global Investigation of therapeutic decisions in hepatocellular carcinoma and of its treatment with SorafeNib) non-interventional study. Int J Clin Pract. 2012;66(7):675-683.

13. Llovet JM, Ricci S, Mazzaferro V, et al. Sorafenib in advanced hepatocellular carcinoma. N Engl J Med. 2008;359(4):378-390.

14. Peixoto RD, Renouf DJ, Gill S, Cheung WY, Lim HJ. Relationship of ethnicity and overall survival in patients treated with Sorafenib for advanced hepatocellular carcinoma. J Gastrointest Oncol. 2014; 5(4):259-264.

15. Al-Rajabi R, Patel S, Ketchum NS, et al. Comparative dosing and efficacy of Sorafenib in hepatocellular cancer patients with varying liver dysfunction. $J$ Gastrointest Oncol. 2015;6(3):259-267.

16. Schmidt TM, Liu LI, Abraham IE, Uy AB, Dudek AZ. Efficacy and safety of Sorafenib in a racially diverse patient population with advanced hepatocellular carcinoma. Anticancer Res. 2018;38(7):4027-4034.

17. Llovet JM, Brú C, Bruix J. Prognosis of hepatocellular carcinoma: the BCLC staging classification. Semin Liver Dis. 1999;19(3):329-338. 
18. A new prognostic system for hepatocellular carcinoma: a retrospective study of 435 patients: the Cancer of the Liver Italian Program (CLIP) investigators. Hepatology. 1998;28(3):751-755.

19. Sinn DH, Cho JY, Gwak GY, et al. Different survival of Barcelona clinic liver cancer stage $\mathrm{C}$ hepatocellular carcinoma patients by the extent of portal vein invasion and the type of extrahepatic spread. PLoS One. 2015;10(4):e0124434.

20. Wada Y, Takami Y, Matsushima H, et al. The safety and efficacy of combination therapy of Sorafenib and radiotherapy for advanced hepatocellular carcinoma: a retrospective study. Intern Med. 2018;57(10): $1345-1353$.
21. Hu H, Duan Z, Long X, et al. Sorafenib combined with transarterial chemoembolization versus transarterial chemoembolization alone for advanced-stage hepatocellular carcinoma: a propensity score matching study. PLoS One. 2014;9(5):e96620.

22. Choi GH, Shim JH, Kim MJ, et al. Sorafenib alone versus Sorafenib combined with transarterial chemoembolization for advanced-stage hepatocellular carcinoma: results of propensity score analyses. Radiology. 2013;269(2):603-611.

\section{Publish your work in this journal}

Drug Design, Development and Therapy is an international, peerreviewed open-access journal that spans the spectrum of drug design and development through to clinical applications. Clinical outcomes, patient safety, and programs for the development and effective, safe, and sustained use of medicines are the features of the journal, which has also been accepted for indexing on PubMed Central. The manuscript management system is completely online and includes a very quick and fair peer-review system, which is all easy to use. Visit http://www.dovepress.com/testimonials.php to read real quotes from published authors.

Submit your manuscript here: http://www.dovepress.com/drug-design-development-and-therapy-journal 